\title{
Effects of the COVID-19 lockdown on criteria air pollutants in the city of Daegu, the epicenter of South Korea's outbreak
}

\author{
Quang Tran Vuong ${ }^{1} \cdot$ Phan Quang Thang ${ }^{2} \cdot$ Min-Kyu Park ${ }^{1} \cdot$ Sung-Deuk Choi ${ }^{1}$ (i)
}

Received: 19 July 2020 / Accepted: 20 October 2020 / Published online: 28 October 2020

(C) Springer-Verlag GmbH Germany, part of Springer Nature 2020

\begin{abstract}
The outbreak of COVID-19 in Daegu, South Korea, early in 2020 has led this metropolitan city to become one of the major hotspots in the world. This study investigates the association of meteorology and the new daily COVID-19 confirmed cases and the effects of the city lockdown on the variation in criteria air pollutants (CAPs) in Daegu. Ambient temperature and relative humidity were negatively correlated to the new daily cases and played an important role in the spread of COVID-19. Wind speed could enhance the virus transmission through the inhalation of aerosols and/or droplets and contact with fomites. The lockdown has directly decreased the concentrations of CAPs. In particular, reductions of 3.75\% $\left(\mathrm{PM}_{10}\right), 30.9 \%\left(\mathrm{PM}_{2.5}\right), 36.7 \%\left(\mathrm{NO}_{2}\right)$, $43.7 \%$ (CO), and $21.3 \%\left(\mathrm{SO}_{2}\right)$ between the period before and during the outbreak were observed over the entire city. An increase in $\mathrm{O}_{3}(71.1 \%)$ was affected by natural processes and photochemical formation other than the lockdown effects. The three central districts were the areas most affected by the virus and showed the highest reductions in CAPs (except for $\mathrm{O}_{3}$ ) during the outbreak. Apart from the influence of the lockdown, the decreasing trend in CAPs may be a result of the actions taken by the government to mitigate air pollutants nationwide since 2019. The results of this study can be useful for government and medical organizations to understand the behavior of the virus in the atmosphere. Further studies are necessary to explore the detailed influences of the lockdown on the environment and public life.
\end{abstract}

Keywords COVID-19 $\cdot$ Criteria air pollutant $\cdot$ Meteorological condition $\cdot$ Lockdown $\cdot$ Daegu

\section{Introduction}

The coronavirus, namely COVID-19, was first identified in Wuhan City in the Hubei province in China in December 2019 after a local hospital warned about patients with

Quang Tran Vuong and Phan Quang Thang contributed equally to this work as co-first authors

Responsible Editor: Gerhard Lammel

Supplementary Information The online version contains supplementary material available at https://doi.org/10.1007/s11356-02011360-4.

Sung-Deuk Choi

sdchoi@unist.ac.kr

1 Department of Urban and Environmental Engineering, Ulsan National Institute of Science and Technology (UNIST), Ulsan 44919, Republic of Korea

2 Institute of Environmental Technology (IET), Vietnam Academy of Science and Technology (VAST), 18 Hoang Quoc Viet, Cau Giay, Hanoi, Vietnam pneumonia of an unknown etiology ( $\mathrm{Lu}$ et al. 2020). This virus was first reported to the World Health Organization (WHO) on December 31, 2019, and has become a global public health problem. The COVID-19 pandemic has been deemed a global health crisis (Dantas et al. 2020; Sohrabi et al. 2020). By mid-June 2020, the pandemic encompassed more than 8 million infected people and nearly 450,000 deaths around the world. This pandemic has greatly affected human society, including health care, social relationships, and the structure of the economy as well as politics (Berman and Ebisu 2020).

The first confirmed COVID-19 case in South Korea on January 20, 2020, was a woman who returned from a trip to Wuhan, China, after which the speed of the spread of the secondary transmissions accelerated (Lim et al. 2020). The city of Daegu, South Korea, saw the biggest COVID-19 outbreak outside of China, with a total of nearly 6700 confirmed cases in March 2020, accounting for 90\% of the total nationwide. Patient no. 31 of South Korea, who did not travel to any area affected by COVID-19, was the first confirmed case in Daegu. Following this patient, Daegu and the surrounding 
areas reported hundreds of new cases every day (Her 2020). However, South Korea was able to control the pandemic of new infections early on, maintaining low mortality rates. The effectiveness of the South Korean government actions was demonstrated by the development of a rapid test kit for the testing of a large number of people who were suspected to be positive with the COVID-19 virus, also indicating the high level of responsibility assumed by these people (Oh et al. 2020). To control the spread of COVID-19, the authorities of Daegu implemented various administrative regulations to prevent the outbreak of COVID-19. For example, on March 25, 2020, all citizens were requested to self-quarantine and maintain social distancing (Ma and Kang 2020).

Recent studies on the effects of a lockdown or social distancing on the air quality have attracted much interest. For instance, the association between the six criteria air pollutants (CAPs: $\mathrm{PM}_{2.5}, \mathrm{PM}_{10}, \mathrm{SO}_{2}, \mathrm{CO}, \mathrm{NO}_{2}$, and $\mathrm{O}_{3}$ ) and COVID-19 patients in China has been investigated, and findings suggest that the short-term exposure to air pollutants and the risk of COVID-19 infection showed significant relationships (Zhu et al. 2020). The lockdown has led to a reduction of air pollutants mainly due to the low density of vehicles circulating in cities such as Milan, Italy, resulting in a sharp decrease in $\mathrm{SO}_{2}$ and $\mathrm{NO}_{x}$; however, $\mathrm{O}_{3}$ concentrations tended to increase because of low NO concentrations in the ambient air (Collivignarelli et al. 2020). This finding is consistent with another study in Barcelona, Spain (Tobías et al. 2020), in which $\mathrm{O}_{3}$ concentrations increased by up to $50 \%$. In Sao Paulo, Brazil, the levels of pollutants at an urban site significantly declined during the lockdown period by $77 \%$ (NO), $54 \%\left(\mathrm{NO}_{2}\right)$, and $65 \%(\mathrm{CO})$ compared with a 5-year monthly mean (Nakada and Urban 2020). In addition, several previous studies have shown that the concentrations of $\mathrm{PM}_{2.5}$ and $\mathrm{PM}_{10}$ sharply decreased during the COVID-19 lockdown. These reductions of the CAP levels are one of the positive effects of the COVID-19 lockdown on the environment, not considering the negative ones on the socio-economy (Chauhan and Singh 2020; Mahato et al. 2020; Tobías et al. 2020).

In this study, the relationship between the new daily COVID-19 confirmed cases and hourly meteorological data (ambient temperature, relative humidity, and wind speed) in Daegu during the first 4 months of 2020 was investigated. The variation in hourly CAP $\left(\mathrm{PM}_{10}, \mathrm{PM}_{2.5}, \mathrm{O}_{3}, \mathrm{NO}_{2}, \mathrm{CO}\right.$, and $\mathrm{SO}_{2}$ ) levels before and during the pandemic outbreak was also evaluated.

\section{Materials and methods}

Daegu is one of the largest metropolitan cities in South Korea with a population of $\sim 2.5$ million and a total area of $\sim 900$ $\mathrm{km}^{2}$. In this study, all data were obtained for eight districts (Dong, Buk, Suseong, Seo, Jung, Nam, Dalseo, and
Dalseong) in Daegu. Statistical data for the confirmed COVID-19 cases in Daegu classified by district were downloaded from the official websites of each administrative department (Table S1 in the Supplementary Information) for the period between February to April 2020.

To investigate the lockdown impacts on the air quality of Daegu before and during the outbreak, hourly CAP (14 stations: $\mathrm{PM}_{10}, \mathrm{PM}_{2.5}, \mathrm{O}_{3}, \mathrm{NO}_{2}, \mathrm{CO}$, and $\mathrm{SO}_{2}$ ) and meteorological (one observatory: temperature, wind speed, and relative humidity) data were obtained from the Air Korea website (https://www.airkorea.or.kr) and the Korean Meteorological Administration (KMA) (https://data.kma.go.kr), respectively, for the first 4 months of 2020. The locations of the air monitoring stations and the meteorological observatory in Daegu are presented in Fig. 1 and Table S2. The information of measuring instruments for the CAPs and meteorological data is summarized in Table S3.

The first COVID-19 confirmed case in Daegu, or patient no. 31 of South Korea, was reported on February 18, 2020. This patient had physical contact with other people for many days after showing COVID-19 symptoms, leading to the widespread pandemic in Daegu in the following weeks. Therefore, the study period for this paper is divided into (1) January 1-February 17 (before the outbreak) and (2) February 18-April 30 (during the outbreak). To understand the COVID-19 lockdown effects on the concentrations of CAPs, data during the outbreak in 2020 were also compared with those for the same months of 2019 and 2018.

The data distribution and correlations between the new daily COVID-19 confirmed cases and meteorological parameters were evaluated by applying the Shapiro-Wilk normality test and Pearson's and Spearman's correlation analyses, respectively, using SPSS Statistics 23.0 (IBM, USA). Tests to calculate statistically significant differences ( $t$ test and MannWhitney rank sum test) between the CAP data in different years were performed using SigmaPlot 12.0 (Systat Software Inc., USA).

\section{Results and discussion}

\section{Overview of the COVID-19 pandemic in Daegu}

Figure 2 shows the weekly spread of the COVID-19 pandemic during the outbreak period in Daegu. There were over 440 cases within one week (February 24) after the first confirmed case. The incubation of the virus lasts up to 14 days; therefore, the outbreak of COVID-19 in Daegu was at a peak in the second (March 2) and third (March 9) weeks. In particular, the number of confirmed cases significantly increased by 2600 and 2500 in the second and third weeks, respectively, leading to a total of over 5500 cases on March 9. However, efforts from the South Korean government, such as strict 


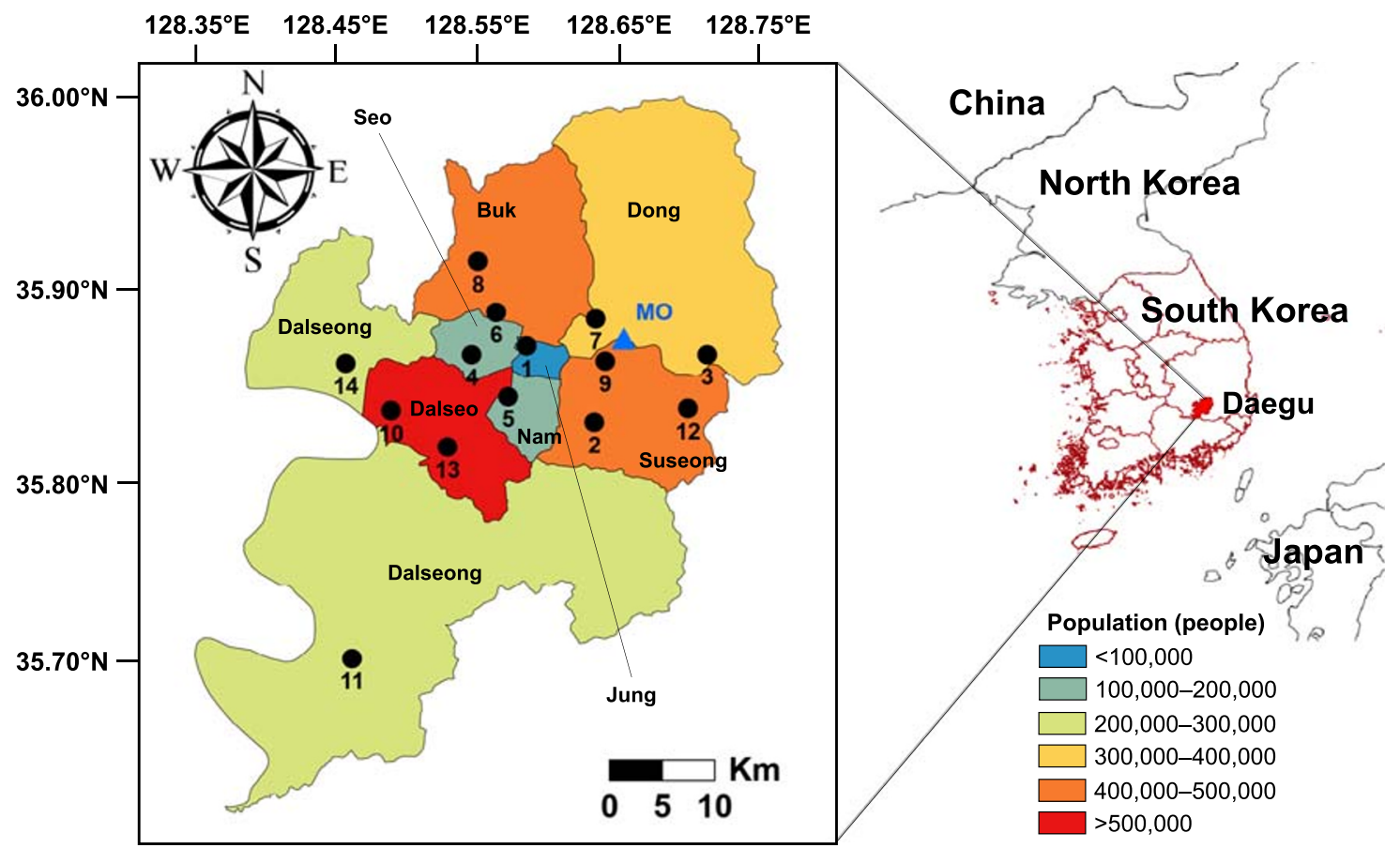

Fig. 1 Locations of 14 air monitoring stations (black circle) and a meteorological observatory (blue triangle) in Daegu, South Korea

social distancing policies and advancements in medical technology, have controlled and prevented the rapid spread of the COVID-19 pandemic in Daegu. As a result, the new cases sharply declined from hundreds to tens during the following weeks in March and April. At the end of April 2020, a total of nearly 6900 confirmed cases were reported, accounting for $60 \%$ of the cases throughout the entire country, when the evolution of the pandemic stabilized. A death rate of $2.5 \%$ (172 cases) from COVID-19 was reported for Daegu, indicating that the treatment methods and actions for the prevention of further spread taken by the government were highly effective.

Figure 3 illustrates the spatial distribution of the pandemic in Daegu during the outbreak period. The most affected districts were Dalseo, Nam, and Suseong, with the total number of cases for each district at approximately 1600, 1300, and

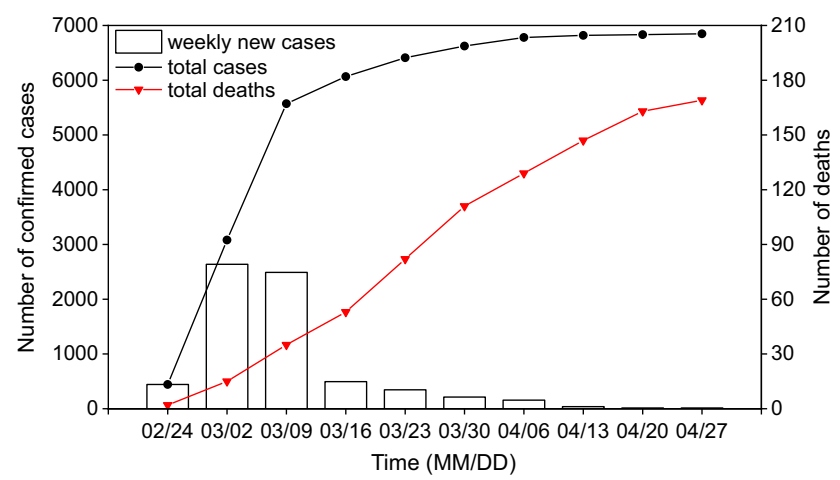

Fig. 2 Weekly data for COVID-19 confirmed cases and deaths from February 18 to April 30, 2020, in Daegu, South Korea
1100, respectively. The spread of COVID-19 in Daegu originated from patient no. 31, a 61-year-old Korean woman and a member of the Shincheonji religious organization. According to the Korea Centers for Disease Control and Prevention, the transmission pathways initiating from patient no. 31 were mainly within the Suseong and Nam districts. More specifically, patient no. 31 went to medical centers and hospitals in the Suseong district for a health check between February 7-17 and left the hospital to attend church in the Nam district on February 9 and February 16. At least 1000 other members of the Shincheonji Church were exposed to COVID-19 by

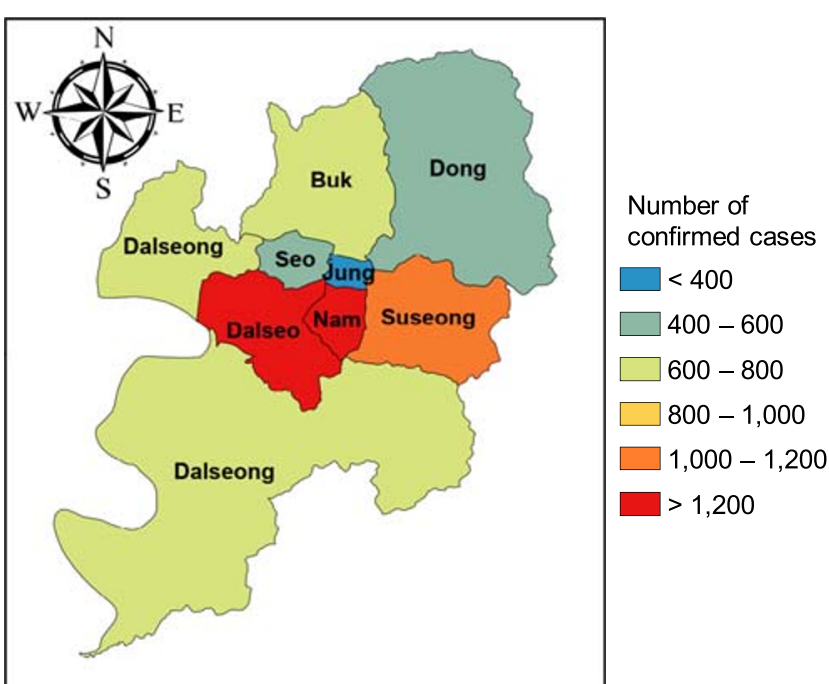

Fig. 3 Spatial distribution map of the total COVID-19 confirmed cases from February 18 to April 30, 2020, in Daegu, South Korea 
patient no. 31 . In addition, Dalseo $(\sim 560,000$ people $)$ and Suseong ( 420,000 people) districts have the highest population in Daegu (Fig. 1). For this reason, Dalseo, Nam, and Suseong districts became the hotspots of the COVID-19 pandemic.

\section{Relationship between the new daily confirmed cases and meteorological conditions}

The incubation period of COVID-19 symptoms normally lasts 14 days; hence, the meteorological conditions at the same time as (0-day lag), 7 days prior (7-day lag), and 14 days prior (14day lag) to the outbreak were evaluated in this study. South Korea is located in the temperate zone of the northern hemisphere with winter-to-spring weather from February to April. In general, the weather conditions during these three periods are quite similar (Table 1) with low mean temperatures (8-10 $\left.{ }^{\circ} \mathrm{C}\right)$, low wind speeds $(2.6 \mathrm{~m} / \mathrm{s})$, and low relative humidity $(58 \%)$.

The human-to-human transmission routes of COVID-19 are the inhalation of aerosols or droplets (Jayaweera et al. 2020) and contact with fomites (WHO 2020). Virus-laden droplets and aerosols can travel under the effects of wind speed by distances from less than $2 \mathrm{~m}$ with normal exhalation (Chen et al. 2020; Ong et al. 2020) and more than $6 \mathrm{~m}$ with cough and sneeze (Jayaweera et al. 2020). However, the lifetime of COVID-19 is $1-5$ and $1-18 \mathrm{~h}$ in aerosols and on the furniture surfaces (made of copper, cardboard, stainless steel, or plastic), respectively (van Doremalen et al. 2020). Therefore, an increase in wind speed at 0 -day lag could have dispersed the virus and enhanced its transmission through human inhalation. Our result also indicates that wind speed was positively correlated to the new daily cases in Daegu at 0-day lag $(r=0.595, p<0.01)$ (Table 2), which is also reported in previous studies (Bashir et al. 2020; Coşkun et al. 2021). Under low wind speeds, virus-laden droplets may deposit quickly on the surface of clothes and/or furniture, favoring the transmission through contact with fomites. Thus, there was a significantly negative correlation between the new daily cases and wind speed at 7-day lag $(r=-0.246, p<0.05)$ (Table 2).

Table 1 Hourly meteorological conditions (mean \pm standard deviation) on the same day as (0-day lag), seven days prior (7-day lag), and 14 days prior (14-day lag) to the outbreak of the COVID-19 pandemic in Daegu, South Korea

\begin{tabular}{llll}
\hline & 0-day lag & 7-day lag & 14-day lag \\
\hline Mean temperature $\left({ }^{\circ} \mathrm{C}\right)$ & $10 \pm 5.4$ & $9.4 \pm 5.2$ & $8.4 \pm 5.7$ \\
Wind speed $(\mathrm{m} / \mathrm{s})$ & $2.6 \pm 1.8$ & $2.7 \pm 1.8$ & $2.5 \pm 1.7$ \\
Relative humidity $(\%)$ & $58 \pm 23$ & $60 \pm 22$ & $58 \pm 22$ \\
\hline
\end{tabular}

Table 2 Spearman's correlation analysis between the new daily COVID-19 confirmed cases and meteorological parameters at the same time as (0-day lag), 7 days prior (7-day lag), and 14 days prior (14-day lag) to the outbreak of the COVID-19 pandemic in Daegu, South Korea

\begin{tabular}{llll}
\hline & 0-day lag & 7-day lag & 14-day lag \\
\hline Mean temperature & $-0.400^{* *}$ & $-0.244^{*}$ & $0.567^{* * a}$ \\
Wind speed & $0.595^{* *}$ & $-0.246^{*}$ & 0.233 \\
Relative humidity & $-0.316^{* *}$ & $-0.316^{* *}$ & -0.090 \\
\hline
\end{tabular}

*Significant at the 0.05 level; **significant at the 0.01 level

a Pearson's correlation

According to a previous study on the regional climate impacts, the transmission of COVID-19 was highly favored in temperate and dry zones; ambient temperature and relative humidity showed significantly negative correlations with new cases (Méndez-Arriaga 2020; Qi et al. 2020). These findings are in line with those in our study. The new daily cases in Daegu were negatively correlated to mean temperature and relative humidity at 0 -day lag $(r=-0.400$ and $r=-0.316$, $p<0.01)$ and 7-day lag $(r=-0.244, p<0.05$ and $r=-0.316$, $p<0.01$ ), respectively (Table 2 ). Although temperature and relative humidity played a vital role in the spread of COVID19 , the results in our study are different from those in a previous study (Auler et al. 2020); in tropical Brazil, high temperatures $\left(28{ }^{\circ} \mathrm{C}\right)$ and intermediate relative humidity $(80 \%)$ increased the spread of COVID-19. As the incubation period for COVID-19 is up to 14 days, the relationship between the new daily cases and meteorological conditions was somewhat unclear at 14-day lag. In particular, the correlations were not significant for wind speed and relative humidity $(p>0.05)$ and shifted from negative to positive for mean temperature (Table 2). In short, meteorological conditions (e.g., temperature, wind speed, and relative humidity) may significantly affect the transmission of COVID-19 (Bashir et al. 2020); however, the degree and direction of these effects may be different between tropical and temperate climates. These results indicate that the existence and evolution of the coronavirus may be complex. Further investigation is necessary to fully understand the behavior of this virus.

\section{Lockdown effects on CAPs}

The CAP concentrations during the outbreak of COVID-19 (February 18-April 30) in 2020 were compared with those for the same months in 2019 and 2018 in Daegu (Table 3). Except for the relatively constant level of $\mathrm{O}_{3}$ for all 3 years, all other CAPs showed clear reductions. These trends are consistent with those in previous studies (Abdullah et al. 2020; Collivignarelli et al. 2020; Dantas et al. 2020; Nakada and Urban 2020). In particular, there was a decrease of $24.3 \%$ $\left(\mathrm{PM}_{10}\right), 29.6 \%\left(\mathrm{PM}_{2.5}\right), 20.0 \%\left(\mathrm{NO}_{2}\right), 9.51 \%(\mathrm{CO})$, and 
Table 3 Comparison of the CAP concentrations during selected periods in Daegu, South Korea

\begin{tabular}{llllll}
\hline & Feb 18-Apr 30, 2018 & Feb 18-Apr 30, 2019 & Feb 18-Apr 30, 2020 & Jan 1-Feb 17, 2020 $^{\text {Difference }^{\mathrm{a}}}$ \\
\hline $\mathrm{PM}_{10}\left(\mu \mathrm{g} / \mathrm{m}^{3}\right)$ & $50.6 \pm 32.8$ & $48.8 \pm 27.5$ & $37.5 \pm 18.9$ & $38.9 \pm 20.8$ & $-1.4(3.75)^{\mathrm{b}}$ \\
$\mathrm{PM}_{2.5}\left(\mu \mathrm{g} / \mathrm{m}^{3}\right)$ & $26.2 \pm 16.5$ & $27.8 \pm 19.9$ & $19.3 \pm 10.7$ & $27.9 \pm 16.9$ & $-8.6(30.9)$ \\
$\mathrm{O}_{3}(\mathrm{ppb})$ & $32.3 \pm 19.3$ & $34.5 \pm 19.0$ & $33.4 \pm 17.8$ & $19.6 \pm 14.3$ & $13.8(71.1)$ \\
$\mathrm{NO}_{2}(\mathrm{ppb})$ & $20.4 \pm 13.8$ & $20.8 \pm 13.8$ & $16.3 \pm 12.1$ & $25.8 \pm 14.7$ & $-9.5(36.7)$ \\
$\mathrm{CO}(\mathrm{ppb})$ & $425 \pm 192$ & $478 \pm 202$ & $409 \pm 145$ & $3.4 \pm 1.5$ & $-317(43.7)$ \\
$\mathrm{SO}_{2}(\mathrm{ppb})$ & $3.1 \pm 1.8$ & $2.9 \pm 1.5$ & $2.7 \pm 1.2$ & $-0.7(21.3)$ \\
\hline
\end{tabular}

${ }^{\text {a }}$ Difference between February 18-April 30, 2020, and January 1-February 17, 2020

${ }^{\mathrm{b}}$ Concentration (percentage)

$11.5 \%\left(\mathrm{SO}_{2}\right)$ between CAP levels in 2020 and the average CAP levels for 2019 and 2018. Wind speed and precipitation between February 18 and April 30 in these three consecutive years were also considered to evaluate the impacts of meteorological conditions on the CAP levels in Daegu. Wind patterns (Fig. S1 in the Supplementary Information) were similar for all three years with an average wind speed of $2.4 \mathrm{~m} / \mathrm{s}$, whereas precipitation reduced from $237 \mathrm{~mm}$ in 2018 to $129 \mathrm{~mm}$ in 2019 and then to $87 \mathrm{~mm}$ in 2020 . Therefore, the decreasing trend in CAPs may not be completely influenced by meteorological conditions. To investigate the impacts of the COVID-19 lockdown on the current changes in air quality in Daegu, the following results and discussion focus on the CAP levels between January 1-February 17, 2020 (before the outbreak) and February 18-April 30, 2020 (during the outbreak).

Boxplots of the CAP concentrations before and during the outbreak of COVID-19 in Daegu are illustrated in Fig. 4. There were statistically significant differences between the CAP concentrations of these two periods (Mann-Whitney rank sum test, $p<0.01)$. $\mathrm{PM}_{10}$ slightly declined by $3.75 \%$ from 38.9 to $37.5 \mu \mathrm{g} / \mathrm{m}^{3}$. This reduction percentage is approximately one-third of that in Rio de Janeiro, Brazil (Dantas et al. 2020), and one-tenth of that in Milan, Italy (Collivignarelli et al. 2020). Asian dust, mostly originating from natural sources (e.g., deserts and loess areas), has been reported to abundantly appear during these months in South Korea (Choi et al. 2012; Kim 2008; Kim et al. 2009; Matsumoto et al. 2006). According to the KMA, in Daegu, there were several days with typically high levels of $\mathrm{PM}_{10}$, which are defined as Asian dust. For example, the maximum hourly concentrations of $\mathrm{PM}_{10}$ on February 22 (09:00-20:00, UTC+9) and March 19 (12:00-17:00, UTC+9) were 124 and $122 \mu \mathrm{g} / \mathrm{m}^{3}$, respectively. Therefore, the reduction of $\mathrm{PM}_{10}$ in Daegu during the spread of COVID-19 was less than that in Rio de Janeiro and Milan. Regarding $\mathrm{PM}_{2.5}$, its decreasing trend is more evident than that of $\mathrm{PM}_{10}$ with a decrease of $30.9 \%$ from 27.9 to $19.3 \mu \mathrm{g} / \mathrm{m}^{3}$ in Daegu and comparable with that of $\mathrm{PM}_{2.5}$ in many cities of Malaysia (with a decrease of 28.3\%) (Abdullah et al. 2020) but less than that of $\mathrm{PM}_{2.5}$ in Milan (with a decrease $>40 \%$ ) (Collivignarelli et al. 2020). The strict social distancing policy was implemented in Daegu to prevent human-to-human transmission of the virus, leading to a large limitation in the circulation of vehicles. Thus, $\mathrm{NO}_{2}$ and $\mathrm{CO}$, which have been reported to be mainly produced by vehicular emissions (Clarke et al. 2014), reduced significantly by $36.7 \%$ from 25.8 to $16.3 \mathrm{ppb}$ and $43.7 \%$ from 726 to $409 \mathrm{ppb}$, respectively. Previous studies have indicated that $\mathrm{NO}_{2}$ decreased by $47 \%$ in Milan (Collivignarelli et al. 2020) and 50\% in Barcelona, Spain (Tobías et al. 2020), which are greater decreases than that in Daegu. However,
Fig. 4 Concentrations of CAPs before (January 1-February 17, 2020) and during the COVID-19 pandemic outbreak (February 18 April 30, 2020) in Daegu, South Korea

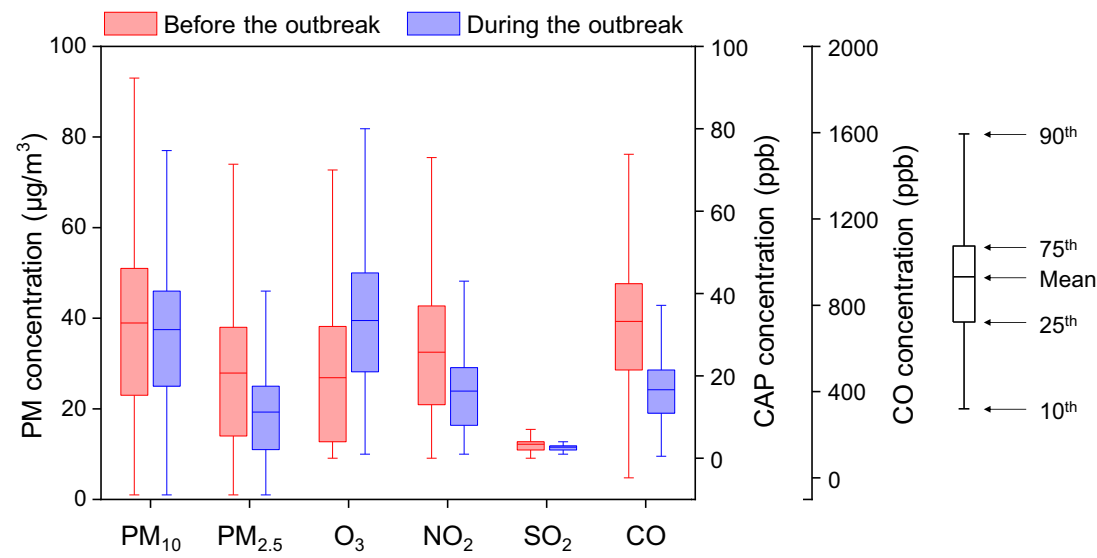


the reduction of CO in Daegu is similar to that in Milan (46\%) (Collivignarelli et al. 2020) and Rio de Janeiro (40\%) (Dantas et al. 2020) and less than that in Sao Paulo, Brazil (65\%) (Nakada and Urban 2020). Regarding $\mathrm{SO}_{2}$, a reduction of $21.3 \%$ from 3.4 to $2.7 \mathrm{ppb}$ in Daegu is comparable with that in Milan (25\%) (Collivignarelli et al. 2020). Although Daegu is not a major industrial city, its neighboring cities (e.g., Ulsan and Pohang) include the largest industrial zones in South Korea. During the outbreak of COVID-19, the closure of factories may have caused a decline in $\mathrm{SO}_{2}$ emissions in those cities, which in turn influenced the air quality of Daegu by short-range transport.

In South Korea, $\mathrm{NO}_{2}$ and $\mathrm{CO}$ have been reported to usually be higher from December to March in Daegu (Jo and Park 2005), Daejon (Jung et al. 2017), Seoul (Pandey et al. 2008), and Ulsan (Clarke et al. 2014), whereas the level of $\mathrm{SO}_{2}$ increases from November to February in Daegu (Jo and Park 2005) due to seasonal factors (e.g., low temperatures and increasing demand for heating). Therefore, the South Korean government introduced several policies at the end of 2019 to improve the air quality of the whole country. According to the Ministry of Environment, the Special Measures to Respond to High Levels of Fine Dust and the Fine Dust Seasonal Management System were introduced in November 2019 to reduce the intensity and recurrence of high concentrations of $\mathrm{PM}_{2.5}$ during the typical period of its occurrence (MOE 2020). In particular, the operation of coal-fired power plants has been suspended, and the upper limit restrictions on air pollutant emissions have been applied to many industrial facilities. Furthermore, the 5th Grade Vehicle Operation Restrictions (in terms of air pollutant emissions) and the Alternative NoDriving System of Public Vehicles have been issued for citizens and implemented in many metropolitan cities. These actions from the government may also be partly responsible for the improvements in air quality in Daegu during the outbreak of the pandemic in 2020.

$\mathrm{O}_{3}$ is known as a secondary pollutant produced from solar radiation and its precursors (e.g., $\mathrm{NO}_{2}, \mathrm{CO}$, and volatile organic compounds-VOCs). Previous studies in Daegu (Jo and Park 2005) and Ulsan, South Korea (Clarke et al. 2014), have shown that $\mathrm{O}_{3}$ reaches its annual maximum level in the spring season (March, April, and May). Additionally, under the condition of a low $\mathrm{VOC} / \mathrm{NO}_{x}$ ratio in the urban city (VOClimited), a decrease in $\mathrm{NO}_{x}$ may lead to the suppressed titration of $\mathrm{O}_{3}$, increasing the formation of tropospheric $\mathrm{O}_{3}$ (Jo and Park 2005; NRC 1991; Park et al. 2018). In our study, the concentration of $\mathrm{O}_{3}$ significantly increased by $71.1 \%$ during the outbreak of COVID-19 compared with the period right before the outbreak with an observed reduction of $36.7 \%$ in $\mathrm{NO}_{2}$ (Table 3). However, $\mathrm{O}_{3}$ showed very similar levels on January 1-February 17 ( $19 \mathrm{ppb})$ and February 18-April 30 $(\sim 33 \mathrm{ppb})$ in 2020, 2019, and 2018. An increase in ambient temperature, mostly because of the solar radiation, from $3.9 \pm$
$4.2{ }^{\circ} \mathrm{C}$ (before the outbreak) to $10 \pm 5.4{ }^{\circ} \mathrm{C}$ (during the outbreak) may enhance the photochemical formation of $\mathrm{O}_{3}$ (Mukherjee et al. 2020). In addition, generation pathways from natural processes have also been proposed to explain the increase in $\mathrm{O}_{3}$ during these three months (Monks 2000). For example, $\mathrm{O}_{3}$ has been reported to increase in the spring due to a phenomenon at the northern-hemisphere scale (Simmonds et al. 1997) and the intrusion of stratospheric $\mathrm{O}_{3}$ into the troposphere (Levy II et al. 1985; Tu et al. 2007). Therefore, the influence of the COVID-19 lockdown on the sharp increase in $\mathrm{O}_{3}$ is still unclear in our study. This pattern observed for $\mathrm{O}_{3}$ may be due to annual natural processes rather than the reduction of $\mathrm{NO}$ that consumes tropospheric $\mathrm{O}_{3}$ as mentioned in other studies (Collivignarelli et al. 2020; Tobías et al. 2020).

To investigate the spatial impacts of the COVID-19 lockdown on the air quality of Daegu, spatial distribution maps of the average CAP concentrations before and during the outbreak are shown in Fig. 5. The most affected districts by the pandemic (Dalseo, Nam, and Suseong districts) showed the most apparent reductions in the CAP levels. As explained above, an increase in the $\mathrm{O}_{3}$ concentration may be influenced by several factors other than the lockdown; therefore, this pattern is not discussed further. The average decrease in concentrations of $\mathrm{PM}_{10}$ (9.17\%), $\mathrm{PM}_{2.5}$ (35.1\%), $\mathrm{NO}_{2}$ (36.8\%), and $\mathrm{CO}(50.3 \%)$ was the highest in the Suseong district (sites $2,3,9$, and 12), whereas the highest decrease in $\mathrm{SO}_{2}(55.9 \%)$ was observed in the southeastern part of the Dalseo district (site 13) in Daegu. These tendencies can be explained by the restrictions on mobility and/or the partial and total lockdowns for all workplaces and educational facilities due to the rapid spread of COVID-19 in these three districts during the first half of March 2020.

\section{Conclusion}

The COVID-19 pandemic struck Daegu, South Korea, resulting in a total of $\sim 5500$ cases within the first 3 weeks of its outbreak (February 18-March 9, 2020). The South Korean government responded quickly to the pandemic by imposing partial and total lockdowns of the city to prevent human-to-human transmission of the virus; therefore, the situation was stabilized in April 2020 with a total of $\sim 6900$ cases and a death rate of $2.5 \%$ (172 cases). Three central districts were the most affected areas by COVID-19, with 1600 cases in Dalseo, 1300 cases in Nam, and 1100 cases in Suseong. Meteorological conditions were vital factors for the spread of COVID-19. In particular, the new daily cases were significantly negatively correlated to the mean ambient temperature and relative humidity at both 0-day and 7-day lag, while the relationship between the new daily cases and wind speed was significantly positive at 0 -day lag and negative at 7 -day lag. 


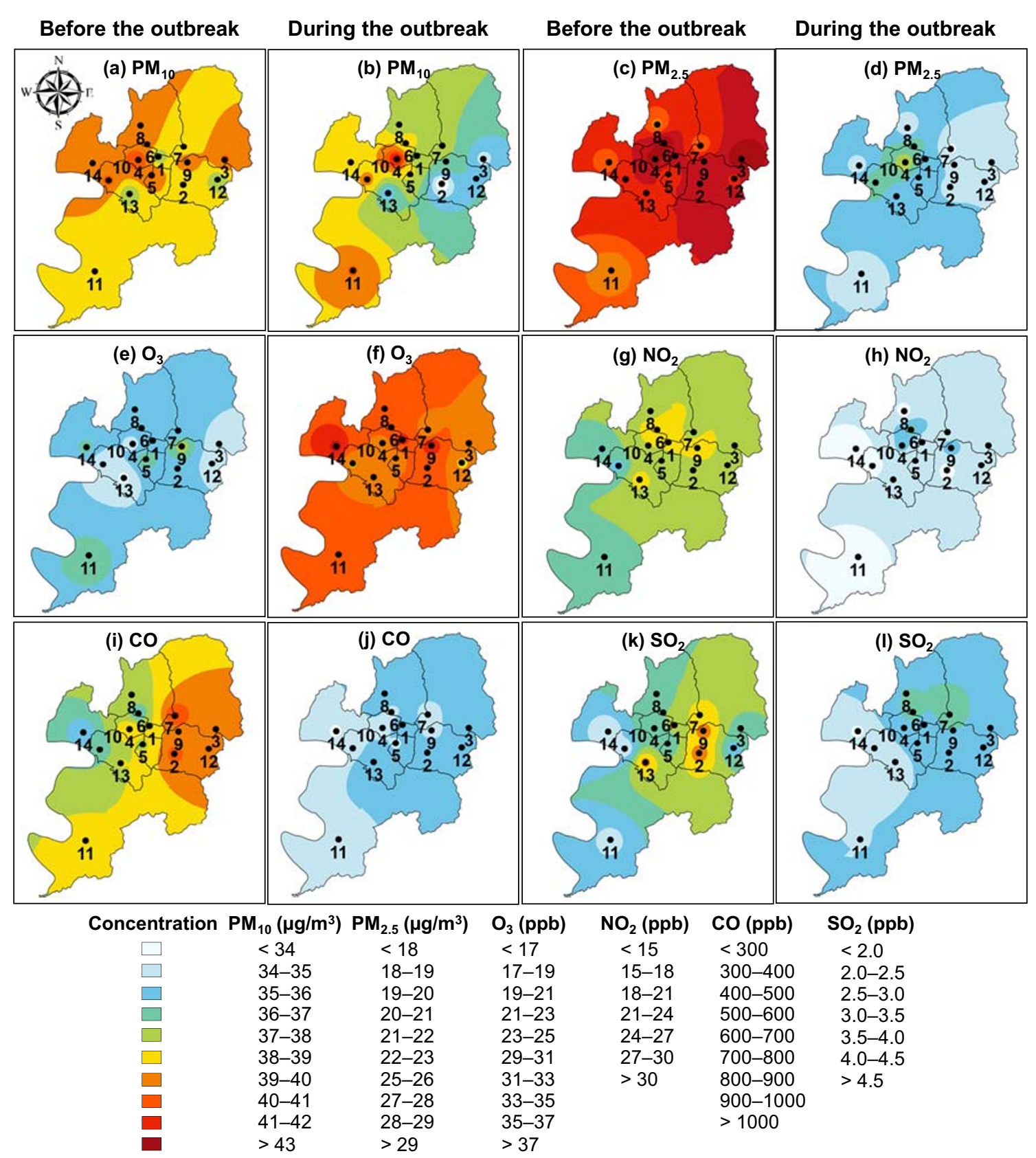

Fig. 5 Spatial distribution maps of the average CAP concentrations before (January 1-February 17, 2020) and during the COVID-19 pandemic outbreak (February 18-April 30, 2020) in Daegu, South Korea.

Actions taken by the government to protect human health from the pandemic have also directly influenced the air quality of Daegu.

The concentration of $\mathrm{PM}_{10}$ during the outbreak only slightly decreased compared with that before the outbreak, whereas the levels of $\mathrm{PM}_{2.5}, \mathrm{NO}_{2}, \mathrm{CO}$, and $\mathrm{SO}_{2}$ significantly decreased over the entire city. This decreasing trend was the most apparent in the three central districts (Dalseo, Nam, and Suseong). However, an increase in $\mathrm{O}_{3}$ was not clearly affected by the lockdown, but other factors were involved. In addition to the major effects of the lockdown, policies by the government to
Contour maps were drawn using ArcGIS 10.8 (ESRI Inc., USA), and inverse distance weighting (IDW) was applied as an interpolation method

improve the air quality for South Korea since the end of 2019 have partly influenced the decreasing trend in CAPs.

In conclusion, the city lockdown has had a negative impact on the socio-economy but a positive impact on the air quality of Daegu. The findings in our exploratory study can serve as fundamental knowledge to both scientists and the government to understand the behavior of the virus and to prevent its rapid spread. As a further study, the influence of the lockdown on the levels of hazardous air pollutants (e.g., polycyclic aromatic hydrocarbons, metals, and VOCs) and their health risks needs to be investigated. 
Authors' contributions Writing — original draft, conceptualization: QTV; writing - original draft: PQT; data curation: MKP; supervision, project administration: SDC.

Funding This research was supported by "Basic Science Research Program" (2020R1A6A1A03040570) through the National Research Foundation of Korea (NRF), "Human Resources Program in Energy Technology (20164030201010 and 20184030202250)" through the Korea Institute of Energy Technology Evaluation and Planning (KETEP), and "Cooperative Research Program for Agriculture Science \& Technology Development (PJ014297)" through Rural Development Administration.

Data availability The datasets used and/or analyzed during the current study are available from the corresponding author on reasonable request.

\section{Compliance with ethical standards}

Ethics approval and consent to participate Not applicable

Consent for publication Not applicable.

Competing interests The authors declare that they have no competing interests.

\section{References}

Abdullah S, Mansor AA, Napi NNLM, Mansor WNW, Ahmed AN, Ismail M, Ramly ZTA (2020) Air quality status during 2020 Malaysia Movement Control Order (MCO) due to 2019 novel coronavirus (2019-nCoV) pandemic. Sci Total Environ 729:139022. https://doi.org/10.1016/j.scitotenv.2020.139022

Auler AC, Cássaro FAM, da Silva VO, Pires LF (2020) Evidence that high temperatures and intermediate relative humidity might favor the spread of COVID-19 in tropical climate: a case study for the most affected Brazilian cities. Sci Total Environ 729:139090. https://doi.org/10.1016/j.scitotenv.2020.139090

Bashir MF, Ma B, Bilal KB, Bashir MA, Tan D, Bashir M (2020) Correlation between climate indicators and COVID-19 pandemic in New York, USA. Sci Total Environ 728:138835. https://doi.org/ 10.1016/j.scitotenv.2020.138835

Berman JD, Ebisu K (2020) Changes in U.S. air pollution during the COVID-19 pandemic. Sci Total Environ 739:139864. https://doi. org/10.1016/j.scitotenv.2020.139864

Chauhan A, Singh RP (2020) Decline in $\mathrm{PM}_{2.5}$ concentrations over major cities around the world associated with COVID-19. Environ Res 187:109634. https://doi.org/10.1016/j.envres.2020.109634

Chen W, Zhang N, Wei J, Yen H-L, Li Y (2020) Short-range airborne route dominates exposure of respiratory infection during close contact. Build Environ 176:106859. https://doi.org/10.1016/j.buildenv. 2020.106859

Choi S-D, Ghim YS, Lee JY, Kim JY, Kim YP (2012) Factors affecting the level and pattern of polycyclic aromatic hydrocarbons (PAHs) at Gosan, Korea during a dust period. J Hazard Mater 227-228:79-87. https://doi.org/10.1016/j.jhazmat.2012.05.012

Clarke K, Kwon H-O, Choi S-D (2014) Fast and reliable source identification of criteria air pollutants in an industrial city. Atmos Environ 95:239-248. https://doi.org/10.1016/j.atmosenv.2014.06.040

Collivignarelli MC, Abbà A, Bertanza G, Pedrazzani R, Ricciardi P, Carnevale Miino M (2020) Lockdown for CoViD-2019 in Milan: what are the effects on air quality? Sci Total Environ 732:139280. https://doi.org/10.1016/j.scitotenv.2020.139280
Coşkun H, Yıldırım N, Gündüz S (2021) The spread of COVID-19 virus through population density and wind in Turkey cities. Sci Total Environ 751:141663. https://doi.org/10.1016/j.scitotenv.2020. 141663

Dantas G, Siciliano B, França BB, da Silva CM, Arbilla G (2020) The impact of COVID-19 partial lockdown on the air quality of the city of Rio de Janeiro, Brazil. Sci Total Environ 729:139085. https://doi. org/10.1016/j.scitotenv.2020.139085

Her M (2020) How is COVID-19 affecting South Korea? What is our current strategy? Dis Med Public Health Prep:1-3. https://doi.org/10. 1017/dmp.2020.69

Jayaweera M, Perera H, Gunawardana B, Manatunge J (2020) Transmission of COVID-19 virus by droplets and aerosols: a critical review on the unresolved dichotomy. Environ Res 188:109819. https://doi.org/10.1016/j.envres.2020.109819

Jo W-K, Park J-H (2005) Characteristics of roadside air pollution in Korean metropolitan city (Daegu) over last 5 to 6 years: temporal variations, standard exceedances, and dependence on meteorological conditions. Chemosphere 59:1557-1573. https://doi.org/10. 1016/j.chemosphere.2004.12.021

Jung J, Lee J, Kim B, Oh S (2017) Seasonal variations in the $\mathrm{NO}_{2}$ artifact from chemiluminescence measurements with a molybdenum converter at a suburban site in Korea (downwind of the Asian continental outflow) during 2015-2016. Atmos Environ 165:290-300. https://doi.org/10.1016/j.atmosenv.2017.07.010

Kim J (2008) Transport routes and source regions of Asian dust observed in Korea during the past 40 years (1965-2004). Atmos Environ 42: 4778-4789. https://doi.org/10.1016/j.atmosenv.2008.01.040

Kim NK, Park H-J, Kim YP (2009) Chemical composition change in TSP due to dust storm at Gosan, Korea: do the concentrations of anthropogenic species increase due to dust storm? Water Air Soil Pollut 204:165-175. https://doi.org/10.1007/s11270-009-0035-7

Levy H II, Mahlman JD, Moxim WJ, Liu SC (1985) Tropospheric ozone: the role of transport. J Geophys Res 90:3753-3772. https://doi.org/ 10.1029/JD090iD02p03753

Lim J et al. (2020) Case of the index patient who caused tertiary transmission of coronavirus disease 2019 in Korea: the application of Lopinavir/Ritonavir for the treatment of COVID-19 pneumonia monitored by quantitative RT-PCR. J Korean Med Sci 35. https:// doi.org/10.3346/jkms.2020.35.e79

Lu H, Stratton CW, Tang Y-W (2020) Outbreak of pneumonia of unknown etiology in Wuhan, China: the mystery and the miracle. J Med Virol 92:401-402. https://doi.org/10.1002/jmv.25678

Ma C-J, Kang G-U (2020) Air quality variation in Wuhan, Daegu, and Tokyo during the explosive outbreak of COVID-19 and its health effects. Int J Environ Res Public Health 17(11):4119. https://doi.org/ 10.3390/ijerph17114119

Mahato S, Pal S, Ghosh KG (2020) Effect of lockdown amid COVID-19 pandemic on air quality of the megacity Delhi, India. Sci Total Environ 730:139086. https://doi.org/10.1016/j.scitotenv.2020. 139086

Matsumoto J, Takahashi K, Matsumi Y, Yabushita A, Shimizu A, Matsui I, Sugimoto N (2006) Scavenging of pollutant acid substances by Asian mineral dust particles. Geophys Res Lett 33. https://doi.org/ 10.1029/2006GL025782

Méndez-Arriaga F (2020) The temperature and regional climate effects on communitarian COVID-19 contagion in Mexico throughout phase 1. Sci Total Environ 735:139560. https://doi.org/10.1016/j. scitotenv.2020.139560

MOE (2020) The fine dust seasonal management system. Ministry of Environment. http://eng.me.go.kr/eng/web/board/read.do? pagerOffset $=60 \&$ maxPageItems $=10 \&$ max IndexPages $=$ $10 \& \operatorname{se} \operatorname{archKey}=\& \operatorname{se} \operatorname{arch} V$ alue $=\& \operatorname{menuId}=461 \& \operatorname{orgCd}=$ \&boardId=1127790\&boardMasterId=522\&boardCategoryId= \&decorator $=($ Accessed on Jul 13, 2020) 
Monks PS (2000) A review of the observations and origins of the spring ozone maximum. Atmos Environ 34:3545-3561. https://doi.org/10. 1016/S1352-2310(00)00129-1

Mukherjee S, Singla V, Meena GS, Aslam MY, Safai PD, Buchunde P, Vasudevan AK, Jena CK, Ghude SD, Dani K, Pandithurai G (2020) Sub micron aerosol variability and its ageing process at a high altitude site in India: impact of meteorological conditions. Environ Pollut 265:115019. https://doi.org/10.1016/j.envpol.2020.115019

Nakada LYK, Urban RC (2020) COVID-19 pandemic: impacts on the air quality during the partial lockdown in São Paulo state, Brazil. Sci Total Environ 730:139087. https://doi.org/10.1016/j.scitotenv.2020. 139087

NRC (1991) Rethinking the ozone problem in urban and regional air pollution. National Research Council. Washington, D.C., USA. National Academy Press.

Oh J, Lee J-K, Schwarz D, Ratcliffe HL, Markuns JF, Hirschhorn LR (2020) National response to COVID-19 in the Republic of Korea and lessons learned for other countries. Health Syst Reform 6:e1753464. https://doi.org/10.1080/23288604.2020.1753464

Ong SWX, Tan YK, Chia PY, Lee TH, Ng OT, Wong MSY, Marimuthu K (2020) Air, surface environmental, and personal protective equipment contamination by severe acute respiratory syndrome coronavirus 2 (SARS-CoV-2) from a symptomatic patient. J Am Med Assoc 323: 1610-1612. https://doi.org/10.1001/jama.2020.3227

Pandey SK, Kim K-H, Chung S-Y, Cho SJ, Kim MY, Shon Z-H (2008) Long-term study of NOx behavior at urban roadside and background locations in Seoul, Korea. Atmos Environ 42:607-622. https://doi.org/10.1016/j.atmosenv.2007.10.015

Park S-Y, Park C, Yoo J-W, Lee S-H, Lee HW (2018) Adjoint sensitivity of inland ozone to its precursors and meteorological and chemical influences. Atmos Environ 192:104-115. https://doi.org/10.1016/j. atmosenv.2018.08.006

Qi H, Xiao S, Shi R, Ward MP, Chen Y, Tu W, Su Q, Wang W, Wang X, Zhang Z (2020) COVID-19 transmission in Mainland China is associated with temperature and humidity: a time-series analysis. Sci Total Environ 728:138778. https://doi.org/10.1016/j.scitotenv.2020. 138778
Simmonds PG, Seuring S, Nickless G, Derwent RG (1997) Segregation and interpretation of ozone and carbon monoxide measurements by air mass origin at the TOR Station Mace Head, Ireland from 1987 to 1995. J Atmos Chem 28:45-59. https://doi.org/10.1023/A: 1005817916497

Sohrabi C, Alsafi Z, O'Neill N, Khan M, Kerwan A, al-Jabir A, Iosifidis C, Agha R (2020) World Health Organization declares global emergency: a review of the 2019 novel coronavirus (COVID-19). Int J Surg 76:71-76. https://doi.org/10.1016/j.ijsu.2020.02.034

Tobías A, Carnerero C, Reche C, Massagué J, Via M, Minguillón MC, Alastuey A, Querol X (2020) Changes in air quality during the lockdown in Barcelona (Spain) one month into the SARS-CoV-2 epidemic. Sci Total Environ 726:138540. https://doi.org/10.1016/j. scitotenv.2020.138540

Tu J, Xia Z-G, Wang H, Li W (2007) Temporal variations in surface ozone and its precursors and meteorological effects at an urban site in China. Atmos Res 85:310-337. https://doi.org/10.1016/j. atmosres.2007.02.003

van Doremalen N, Bushmaker T, Morris DH, Holbrook MG, Gamble A, Williamson BN, Tamin A, Harcourt JL, Thornburg NJ, Gerber SI, Lloyd-Smith JO, de Wit E, Munster VJ (2020) Aerosol and surface stability of SARS-CoV-2 as compared with SARS-CoV-1. N Engl J Med 382:1564-1567. https://doi.org/10.1056/NEJMc2004973

WHO (2020) Report of the WHO-China joint mission on coronavirus disease 2019 (COVID-19). World Health Organization. https:// www.who.int/docs/default-source/coronaviruse/who-china-jointmission-on-covid-19-final-report.pdf. Accessed 13 July 2020

Zhu Y, Xie J, Huang F, Cao L (2020) Association between short-term exposure to air pollution and COVID-19 infection: evidence from China. Sci Total Environ 727:138704. https://doi.org/10.1016/j. scitotenv.2020.138704

Publisher's note Springer Nature remains neutral with regard to jurisdictional claims in published maps and institutional affiliations. 